\title{
The Effect of Different Seed Cutting Treatments and Concentrations of BAP for the Successful In Vitro Micrografting of Mangosteen (Garcinia mangostana L.)
}

\author{
Mira Agustina1, Maisura², Rd. Selvy Handayani2* \\ ${ }^{1}$ Master Student of Postgraduate of Agroecotechnology, Faculty of Agriculture, Universitas Malikussaleh, Aceh Utara, Indonesia \\ ${ }^{2}$ Postgraduate of Agroecotechnology, Faculty of Agriculture, Universitas Malikussaleh, Aceh Utara, Indonesia \\ Reuleut Campus, Muara Batu, Aceh Utara 24355, Indonesia \\ *Corresponding author: selvy@unimal.ac.id
}

\section{ARTICLE HISTORY \\ Received : 3 January 2020 \\ Revised : 12 March 2020 \\ Accepted : 14 April 2020}

\section{KEYWORDS}

Apomictic;

Seeds;

Micrografting;

Cytokinin;

\begin{abstract}
The efforts of the rooting of regenerants resulting from gamma-ray irradiation require plant tissue culture, which known as micrografting. This technique can help irradiated regenerants to develop a well root system, by combining non-rooting shoots with rooted in vitro cultured shoots of plant rootstock. The purpose of this study was to examine the effect of seed explants cutting and the application of different BAP concentrations for the successful micro-grafting of mangosteen in vitro. This experiment employed Complete Randomized Design (CRD) Factorial with two factors and ten replications. The first factor was the cutting treatments of mangosteen seeds explants for rootstock shoots, consisting of 2 types of seeds: uncut and cut seeds. The second factor was BAP concentrations: BAP $0 \mathrm{mg} / \mathrm{l}$ and BAP $2 \mathrm{mg} / \mathrm{l}$. The results showed that the division of the seeds had an influence on the results of micro-grafting mangosteen in vitro. Micrografted mangosteen, which rootstock applied from undivided seeds, possessed faster growth, longer shoots, and produce more leaves compared to rootstock shoots from the divided seeds. BAP concentrations also contributed to the results. The application of BAP $2 \mathrm{mg} /$ demonstrated better effect on all variables observed. There were no interactions between seed divisions and BAP concentrations in all observed variables.
\end{abstract}

This is an open-access article under the CC-BY-SA license.

\section{INTRODUCTION}

Mangosteen is one of the horticultural commodities that have high economic value, and it has good prospects for export and the domestic market. Mangosteen is the first export fruit of Indonesia. This tropical fruit is very popular among consumers because it has attractive colors and distinctive taste. Besides, mangosteen is also used as medicines such as anti-inflammatory, anti-bacterial, and as a treatment for infections and injuries (Widiastuti, et al., 2013). Mangosteen skin can be extracted, and it contains very high antioxidants. The content of xanthones on mangosteen skin can be used as a medication for cancer. Mangosteen plants have apomictic seeds, where the seeds are formed without the process of plant reproduction, where the fertilization process does not precede embryo formation. Apomictic seeding produces new plants that have the same characteristics as the parent. Apomictic seeds on mangosteen occur naturally so that it is referred to as natural vegetative propagation.
This apomictic nature of mangosteen seeds attributed to the low level of mangosteen diversity (Mansyah, et al., 2003).

The application of biotechnology is considered as the only way to increase the diversity of mangosteen plants. Biotechnology is a technology that implements biological processes from living organisms to increase production optimally, to produce quality products which safer for consumption with environmentally friendly processes, so that the processes can be sustainable. Research into gamma-ray irradiation in nodular callus culture has been able to increase genetic diversity, but this irradiation on mangosteen is usually producing non-rooting regenerants (Qosim, et al., 2007). Therefore, the effort of the rooting process requires the help of tissue culture treatment through the application of micrografting. Micrografting is an in vitro technique that involves the placement of a meristem or shoots tip explant onto a decapitated 
rootstock that has been grown aseptically from seed or micropropagation cultures (Hussain, et al., 2014). Micrografting technique can help the irradiated regenerants to grow the roots, by grafting the rooted shoots with rooted in vitro rootstock. Experiments on various micrografting techniques in vitro have been widely conducted previously on various plants, for example on the cashew (Ruhnayat \& Syakir, 2014), oranges (Jaskani \& Abbas, 2007), cassava (Rahman, et al., 2017), cactus (Moghadam, et al., 2012) and mangosteen (Handayani, et al., 2013).

One of the factors determining the success of tissue culture is the type of explants and the application of growth regulator (GR). Seeds are one of the plant organs that can be used as a source of explants. Preliminary research results showed that to produce shoots in vitro, mangosteen seeds can be cut even thinly sliced $1 \mathrm{~mm}$ thick, but the smaller the explant, the smaller the shoots produced. Small shoots will complicate the micrografting process and reduce its success rate. Shoots derived from germination of uncut mangosteen seeds have a higher rate of success of micrografting compared to shoots produced from 4-segmented seeds (Handayani, et al., 2013). The growth regulator, which is commonly used to initiate the growth of plant shoots, is cytokinin. Cytokinin is an adenine-derived plant hormone. It functions to stimulate cell division and differentiation of mitosis, is synthesized at the root tip, and it translocates through xylem vessels. One of the synthetic cytokinins commonly used in tissue culture techniques is Benzyl Amino Purine (BAP).

BAP is a group of synthetic cytokinin hormones that are active and have a more prolonged stimulation because they are not easily broken down by plants. In addition, BAP is also a type of growth regulator that is often used because it is most effective for stimulating the formation of shoots, is more stable and resistant to oxidation, and is cheaper than other types of synthetic cytokinins. BAP concentration influences mangosteen germination in vitro in various variables observed. BAP $3 \mathrm{mg} / \mathrm{l}$ possessed better performance compared to other concentrations (Supriati, et al., 2001). BAP concentration of $2.5 \mathrm{ppm}$ was the best concentration for the growth time and the germination percentage of mangosteen in vitro (Handayani, et al., 2017). The purpose of this study was to investigate the effect of seed cutting treatments and the application of BAP for the successful micrografting of mangosteen in vitro.

\section{MATERIALS AND METHODS}

\subsection{Place and Duration}

This research was conducted at Plant Tissue Culture Laboratory, Faculty of Agriculture, Universitas Malikussaleh. The research was carried out from June 2018 to June 2019.

The materials used were sterile mangosteen plants produced from uncut seeds and 2-segmented seeds.
Mangosteen seeds were obtained from mangosteen plantations in Aceh Utara. Other materials used were cloth bleaching and disinfectant Bayclin, alcohol 70\%, spirit burner, fungicides and bactericides, agar, MS, and BAP media. The tools used were the Laminar Air Flow Cabinet, autoclave, oven, $\mathrm{pH}$ meter, and planting equipment.

This research employed Complete Randomized Design (CRD) Factorial with two factors and ten replications. The first factor was the seed cutting treatments for rootstock shoots, consisting of 2 types of treatments: uncut and cut seeds. The second factor was BAP concentrations: BAP 0 $\mathrm{mg} / \mathrm{l}$ and BAP $2 \mathrm{mg} / \mathrm{l}$. In this experiment, the explants were planted in culture bottle jars with an explant per jar, which it was obtained 40 experimental units in total.

The observation was carried out for eight weeks. The observed variables were the percentage of shoot growth, time of shoot growth, shoot length, and a number of leaves resulted from the micrografting process. The purpose of this study was to examine the effect of seed explants cutting and the application of different BAP concentrations for the successful micro-grafting of mangosteen in vitro.

\subsection{Statistical Data Analysis}

Data collected were analyzed statistically using Analysis of Variance (ANOVA). The analysis then was continued using Duncan's Multiple Range Test (DMRT) with probability level $5 \%$ when the $\mathrm{F}$ test results showed significant results between treatments. Data analysis was performed using SAS v9.13 Portable Software.

\section{RESULTS AND DISCUSSIONS}

\subsection{Results}

The results of ANOVA indicated that there was no interaction between mangosteen explants and BAP concentrations on the percentage of shoot growth and shoot growth time. Still, each factor had an effect on the percentage of shoot growth and shoot growth time. The results of further tests of the effect of mangosteen seed explants division and BAP concentrations on the growth time of micrografted shoots in vitro were presented in Table 1.

Table 1. The effect of seed explants division and BAP application on the percentage and time of micrografted shoot growth in vitro

\begin{tabular}{ccc}
\hline Treatments & $\begin{array}{c}\text { Percentage of shoot } \\
\text { growth (\%) }\end{array}$ & $\begin{array}{c}\text { Time of shoot growth } \\
\text { (days after application) }\end{array}$ \\
\hline $\begin{array}{r}\text { Uncut seeds } \\
\text { Cut seeds }(2 \\
\text { segments) }\end{array}$ & $80.55 \mathrm{a}$ & $4.31 \mathrm{~b}$ \\
\hline BAP $0 \mathrm{mg} / \mathrm{l}$ & $74.99 \mathrm{a}$ & $5.55 \mathrm{a}$ \\
BAP $2 \mathrm{mg} / \mathrm{l}$ & $69.44 \mathrm{~b}$ & $5.26 \mathrm{a}$ \\
\hline
\end{tabular}

The values followed by the same letters in the same columns did not differ significantly $(\mathrm{P}=0.05)$ as determined by Duncan's Multiple Range Test 
The results shown in Table 1 described that the seed cutting treatment did not affect the time of micrografted shoot growth. Surprisingly, the uncut seeds demonstrated faster growth to the shoots compared to 2-segmented seeds. The application of BAP $2 \mathrm{mg} / \mathrm{l}$ gave a better

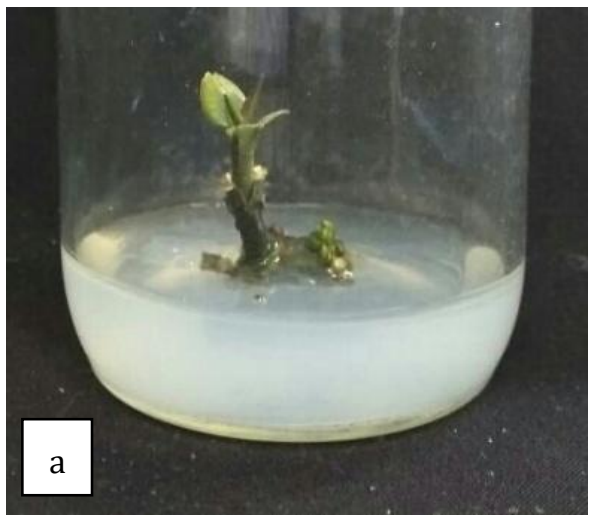

performance with a better percentage of shoot growth, and also it contributed to the shorter time of shoot growth compared to 2-segmented seeds. The pictures of micrografted shoots were shown in Figure 1.

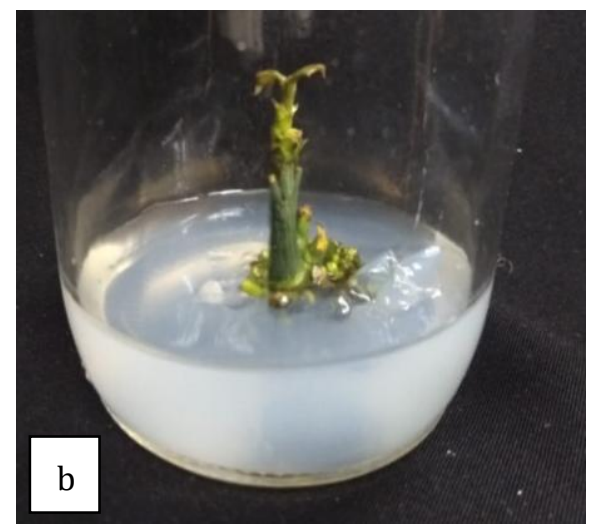

Figure 1. In vitro micrografted shoots. Shoots produced from uncut seeds (a) and shoots produced from 2-segmented seeds

From the figures, we can see that these shoots have different appearances. The shoots micrografted from uncut seeds seem to have better fitness, which is demonstrated by stronger appearance compared to shoots micrografted from 2-segmented seeds. Different cutting treatments and concentrations of BAP also influence the shoot length. The results have been described in Table 2.

Table 2. Time of shoot growth associated with different seed cutting treatments and concentrations of BAP

\begin{tabular}{|c|c|c|c|c|c|c|}
\hline \multirow[b]{2}{*}{ Treatments } & \multicolumn{6}{|c|}{ Shoot Length $(\mathrm{cm})$} \\
\hline & $\begin{array}{c}3 \text { weeks after } \\
\text { application }\end{array}$ & $\begin{array}{c}4 \text { weeks after } \\
\text { application }\end{array}$ & $\begin{array}{c}5 \text { weeks after } \\
\text { application }\end{array}$ & $\begin{array}{c}6 \text { weeks after } \\
\text { application }\end{array}$ & $\begin{array}{c}7 \text { weeks after } \\
\text { application }\end{array}$ & $\begin{array}{c}8 \text { weeks after } \\
\text { application }\end{array}$ \\
\hline \multicolumn{7}{|l|}{ Cutting treatment } \\
\hline Uncut seeds & $0.25(1.12) \mathrm{a}$ & $0.36(1.16) \mathrm{a}$ & $0.53(1.23) \mathrm{a}$ & $0.63(1.27) \mathrm{a}$ & $0.81 \mathrm{a}$ & $0.90 \mathrm{a}$ \\
\hline 2-segmented seeds & $0.23(1.11) \mathrm{a}$ & $0.32(1.15) \mathrm{a}$ & $0.45(1.20) \mathrm{a}$ & $0.50(1.22) \mathrm{a}$ & $0.63 \mathrm{~b}$ & $0.71 \mathrm{~b}$ \\
\hline \multicolumn{7}{|l|}{ BAP Concentrations } \\
\hline $0 \mathrm{mg} / \mathrm{l}$ & $0.23(1.11) \mathrm{a}$ & $0.32(1.15) \mathrm{b}$ & $0.46(1.20) \mathrm{a}$ & $0.52(1.23) \mathrm{b}$ & $0.65 \mathrm{~b}$ & $0.73 \mathrm{~b}$ \\
\hline $2 \mathrm{mg} / \mathrm{l}$ & $0.25(1.12) \mathrm{a}$ & $0.36(1.16) \mathrm{a}$ & $0.51(1.22) \mathrm{a}$ & $0.61(1.26) \mathrm{a}$ & $0.78 \mathrm{a}$ & $0.87 \mathrm{a}$ \\
\hline
\end{tabular}

The values followed by the same letters in the same columns did not differ significantly $(\mathrm{P}=0.05)$, as determined by Duncan's Multiple Range Test. Values in parentheses are transformed values $(\sqrt{ }(\mathrm{x}+1))$

From the results in Table 2, it can be seen that the uncut seeds performed better at 7 and 8 weeks after application. Also, the concentration $2 \mathrm{mg} / \mathrm{l}$ of BAP possessed better shoot development at 6, 7, and 8 weeks after application compared to concentration $0 \mathrm{mg} / \mathrm{l}$ of BAP. We also examined the effect on the leaves. The results were given in Table 3.

Table 3. The effect of seed cutting treatments and concentrations of BAP on number of mangosteen leaves

\begin{tabular}{lccc}
\hline \multirow{2}{*}{ Treatments } & \multicolumn{3}{c}{ Number of leaves (in pairs) } \\
\cline { 2 - 4 } & 4 weeks after application & 6 weeks after application & 8 weeks after application \\
\hline Uncut explants & $1.42(1.54) \mathrm{a}$ & $2.17(1.77) \mathrm{a}$ & $2.66(1.90) \mathrm{a}$ \\
2-segmented explants & $1.20(1.47) \mathrm{a}$ & $1.76(1.64) \mathrm{b}$ & $1.86(1.68) \mathrm{b}$ \\
\hline BAP 0 mg/l & $1.21(1.47) \mathrm{a}$ & $1.75(1.64) \mathrm{b}$ & $2.00(1.76) \mathrm{b}$ \\
BAP 2 mg/l & $1.40(1.53) \mathrm{a}$ & $2.16(1.77) \mathrm{a}$ & $2.50(1.85) \mathrm{a}$ \\
\hline
\end{tabular}

The values followed by the same letters in the same columns did not differ significantly ( $\mathrm{P}=0.05)$, as determined by Duncan's Multiple Range Test. Values in parentheses are transformed values $(\sqrt{(x+1))}$ 
The results in Table 3 revealed that the cutting treatments and the application $2 \mathrm{mg} / \mathrm{l}$ of BAP strongly increased the number of micrografted mangosteen leaves at 6 and 8 weeks after application.

\subsection{Discussion}

The first experiment to be observed in this study was the seed explant cutting, whether it would affect the time of shoot growth, shoot length, and the number of new leaves of mangosteen shoot in vitro. The results showed that the uncut seeds produce shoots with a shorter time, longer shoots, and a better number of leaves compared to cut seeds. However, the seed cutting did not affect the percentage of shoot growth. From the experiments we have done, the uncut seeds demonstrated better results in almost all observed variables, contributed by strong apical dominance possessed by uncut seeds. The young plants of mangosteen, which germinated from uncut seeds, will grow without branch due to the strong apical dominance at the tips of the shoots. It takes two years for these young plants to have some branches. In a successful micrografting process, when the rootstock produced from the germination of uncut seeds is being grafted, it will produce mangosteen seeds with single trunks, which causes the seeds are not able to produce new shoots later. This phenomenon causes the energy for plant growth is diverted at the apex, which resulted in the upper stem to remain vigorous even though it has been micrografted. Therefore, it is estimated that all nutrients absorbed by plants will be more focused on the growth of the micrografted plants.

Seed cutting may contribute to the loss of apical dominance. It often occurs due to injury caused by these cutting treatments. Not only that, seed cutting also allows the seed surface to have direct contact with the media. Explants with wider lesion surfaces will absorb nutrients and growth regulators more rapidly in the media. Cut seeds often produce more shoots compared to uncut seeds, but these shoots become rosette, and only one shoot will usually grow better, and the size is also smaller (Handayani, 2012). This condition definitely will affect the growth of micrografted plants.

It has been proved by some previous researches that micrografted plants resulted from cut seeds, and the shoots will grow from cotyledon even though the micrografting went well. This condition is certainly undesirable because it will cause nutrients competition, which will contribute to the dissatisfying growth of micrografted plants (Handayani, et al., 2013).

The second experiment was to examine the use of BAP concentrations affecting the growth of micrografted mangosteen plants. The results indicated that concentration $2 \mathrm{mg} / \mathrm{l}$ of BAP significantly caused shoots to grow faster, a higher percentage of successful micrografted plants, significant shoot height and also higher number of leaves, if compared with the application of $0 \mathrm{mg} / \mathrm{l}$ BAP. Shoots are the new growth from seed germination that grows upward. The emergence of the shoots in plant explants is often considered as the determination of successful tissue culture research. Inducing this emergence, the growth regulator, such as cytokinin, is often needed. BAP is a type of cytokinin that can generate cell division in plant tissue, and it plays an important role in plant growth and development. Erawati, et al., (2017) found that BAP responsible for stimulating cell growth in plant tissues and stimulating the growth of shoots and leaves of tobacco plants. The application of cytokinin (BAP) to the media can stimulate the meristem cells in explants to divide and influence other cells to develop into new shoots and leaves. This is in accordance with the function of cytokinin, where it can stimulate the growth of mangosteen leaves and shoots in vitro (Nursetiadi, 2008).

Explants have different responses to absorb nutrients. The growth of micrografted explants is influenced by how high the growth regulators applied. The use of growth regulators in small amounts can help the growth of explants (Mandang, 2013). The application of $2 \mathrm{mg} / \mathrm{l}$ of BAP stimulated a shorter time for the formation of pineapple shoots (Purita, et al., 2017). Handayani, et al. (2017) have investigated that the application of $2.5 \mathrm{mg} / \mathrm{l}$ of BAP was the best concentration for shoot growth of mangosteen in vitro. The application of BAP also affects the number of plant leaves. Researches done by Fithriyandini, et al. (2015) and Yudhanto \& Wiendi (2015) confirmed that the application of $2.5 \mathrm{mg} / \mathrm{l}$ BAP on moon orchids and tropical pitcher plants increase their number of leaves. These researches were in line with the study of Ibrahim (2014), who stated that the application of $2 \mathrm{mg} / \mathrm{l}$ BAP had increased the number of coffee leaves.

\section{CONCLUSIONS}

1. Seed cutting treatment influenced the successful in vitro micrografting in mangosteen plants. Micrografted mangosteen plants produced from rootstocks of uncut seeds demonstrated faster growth of shoots, longer shoots, and also an increasing number of leaves compared to cut seeds.

2. Different concentrations of BAP was also influenced by the results in micrografted plants. The application of BAP $2 \mathrm{mg} / \mathrm{l}$ had a better effect on all variables observed.

3. No interaction between seed cutting treatments and the use of BAP concentration in all variables observed.

\section{REFERENCES}

Erawati, D. N., Fisdiana, U., \& Humaida, S. (2018). Peran Benzyl Amino Purine Pada Induksi Tunas Kultur Tembakau White Burley. Jurnal Ilmiah Inovasi, 17(3). doi:10.25047/jii.v17i3.553

Fithriyandini, A., Maghfoer, M. D., \& Wardiyati, T. (2015). Pengaruh media dasar dan 6-benzylaminopurine (BAP) terhadap pertumbuhan dan perkembangan nodus tangkai bunga Anggrek Bulan (Phalaenopsis amabilis) dalam perbanyakan secara in vitro. Jurnal Produksi Tanaman, 
3(1), 43-49.

Handayani R.S. 2012. Rekayasa teknologi sambung mikro dan setek mikro pada tanaman manggis (Garcinia mangostana). Dissertation, Program Pascasarjana, Institut Pertanian Bogor, Bogor.

Handayani, R. S., Maisura, M., \& Rizki, A. (2018). Pengaruh Letak Posisi Eksplan dan Sitokinin Pada Perkecambahan Biji Manggis (Garcinia mangostana L.) Lokal Aceh Secara in-Vitro. Jurnal Agrium, 14(2), 1. doi:10.29103/agrium. v14i2.874

Handayani, R. S., Poerwanto, R., Purwito, A., \& Ermayanti, T. M. (2013). Pengaruh Batang Bawah dan Jenis Tunas pada Mikrografting Manggis (Garcinia mangostana) secara In Vitro. Jurnal Agronomi Indonesia (Indonesian Journal of Agronomy), 41(1).

Hussain,, G., Wani,, M. S., Mir,, M. A., Rather, Z. A., \& Bhat,, K. M. (2014). Micrografting for fruit crop improvement. African Journal of Biotechnology, 13(25), 2474-2483. doi:10.5897/ ajb2013.13602

Ibrahim M.S.D., Hartati R.S. (2014). Multiplikasi Tunas Kopi Arabika Menggunakan Kinetin dan 6-Benzylaminopurine. Prosiding Seminar Nasional Agroinovasi Spesifik Lokasi Untuk Ketahanan Pangan Pada Era Masyarakat Ekonomi ASEAN. 857-864.

Jaskani, M., \& Abbas, H. (2007). In vitro studies on micrografting technique in two cultivars of citrus to produce virus free plants. Pak. J. Bot, 39(5), 1773-1778.

Mandang, J. S. (2013). Media Kultur Jaringan Tanaman. Manado: Bayumedia Publishing Anggota IKAPI.

Mansyah, E. (2012). Struktur genetik manggis (Garcinia mangostana L,) berbasis marka morfologi dan molekuler. Dissertation, Program Pascasarjana, Institut Pertanian Bogor, Bogor.

Moghadam, A. R. L., Ardebili, Z. O., \& Rezaie, L. (2012). Effect of indole butyric acid on micrografting of cactus. African Journal of Biotechnology, 11(24), 6484-6493.
Nursetiadi, E. 2008. Kajian Macam Media dan Konsentrasi BAP terhadap Multiplikasi Tanaman Manggis (Garcinia mangostana L.) Secara In Vitro. Script. Fakultas Pertanian UNS. Surakarta.

Purita, S. Y., Ardiarini, N. R., \& Basuki, N. (2018). Pengaruh Zat Pengatur Tumbuh Jenis Bap Terhadap Pertumbuhan Planlet Sub Kultur Jaringan Tanaman Nanas (Ananas Comosus L. Merr). Jurnal Produksi Tanaman, 5(7), 1207-1212.

Qosim, W.A., R. Poerwanto., G.A., Wattimena, \& Witjaksono. (2007). Pengaruh iradiasi sinar gamma terhadap kapasitas regenerasi kalus nodular tanaman manggis. Hayati Journal of Biosciences, 14(4), 140-144. doi:10.4308/hjb.14.4.140

Rahman, N., Fitriani, H., Hartati, S.N., \& Soedarmonowati, E. (2018). Multiplikasi Tunas Kultur Ubi Kayu dengan Teknik Sambung Pucuk (Grafting) In Vitro. Prosiding Seminar Nasional : Pertanian dan Tanaman Herbal Berkelanjutan di Indonesia. Bogor. LIPI, 229-236.

Ruhnayat, A., \& Syakir, M. (2014). Penyediaan benih jambu mete unggul secara cepat melalui mikro grafting. Sirkuler. Informasi Teknologi Tanaman Rempah dan Obat. Balittro, 26.

Supriati, Y., Sunarlim, N., Adil, W. H., Mariska, I., Rusyadi, Y., Sukmadjaja, D., \& Lestari, E. G. Murtado. 2001. Studi regenerasi tanaman potensial dan bernilai ekonomi tinggi. Laporan Hasil Penelitian Balitbio, Bogor.

Widiastuti, A., Sobir, S., \& Suhartanto, M. R. (2013). Analisis keragaman genetik manggis (Garcinia mangostana) diiradiasi dengan sinar gamma berdasarkan penanda ISSR. Bioteknologi Biotechnological Studies, 10(1), 15-22. doi:10.13057/biotek/c100103

Yudhanto, B. S., \& Wiendi, N. M. A. (2015). Pengaruh Pemberian Auksin (NAA) dengan Sitokinin (BAP, Kinetin dan 2ip) terhadap Daya Proliferasi Tanaman Kantong Semar (Nepenthes mirabilis) Secara In Vitro. Buletin Agrohorti, 3(3), 276-284. doi:10.29244/agrob.v3i3.15799. 